\title{
Serangga Pengunjung Pada Spesies Bunga Anggrek Vanda tricolor
}

\author{
${ }^{1}$ Sukmawati, ${ }^{2}$ Manap Trianto, ${ }^{3}$ Nuraini, ${ }^{4}$ Fajri Marisa, ${ }^{5}$ Moh. Dahri Kisman \\ Fakultas Biologi, Universitas Gadjah Mada, Yogyakarta, Indonesia \\ ${ }^{1}$ sukmawati96@mail.ugm.ac.id, ${ }^{2}$ manaptrianto@mail.ugm.ac.id. ${ }^{3}$ aini77785@mail.ugm.ac.id, \\ ${ }^{4}$ fajrimarisa@mail.ugm.ac.id, ${ }^{5}$ mohdahrikisman@mail.ugm.ac.id
}

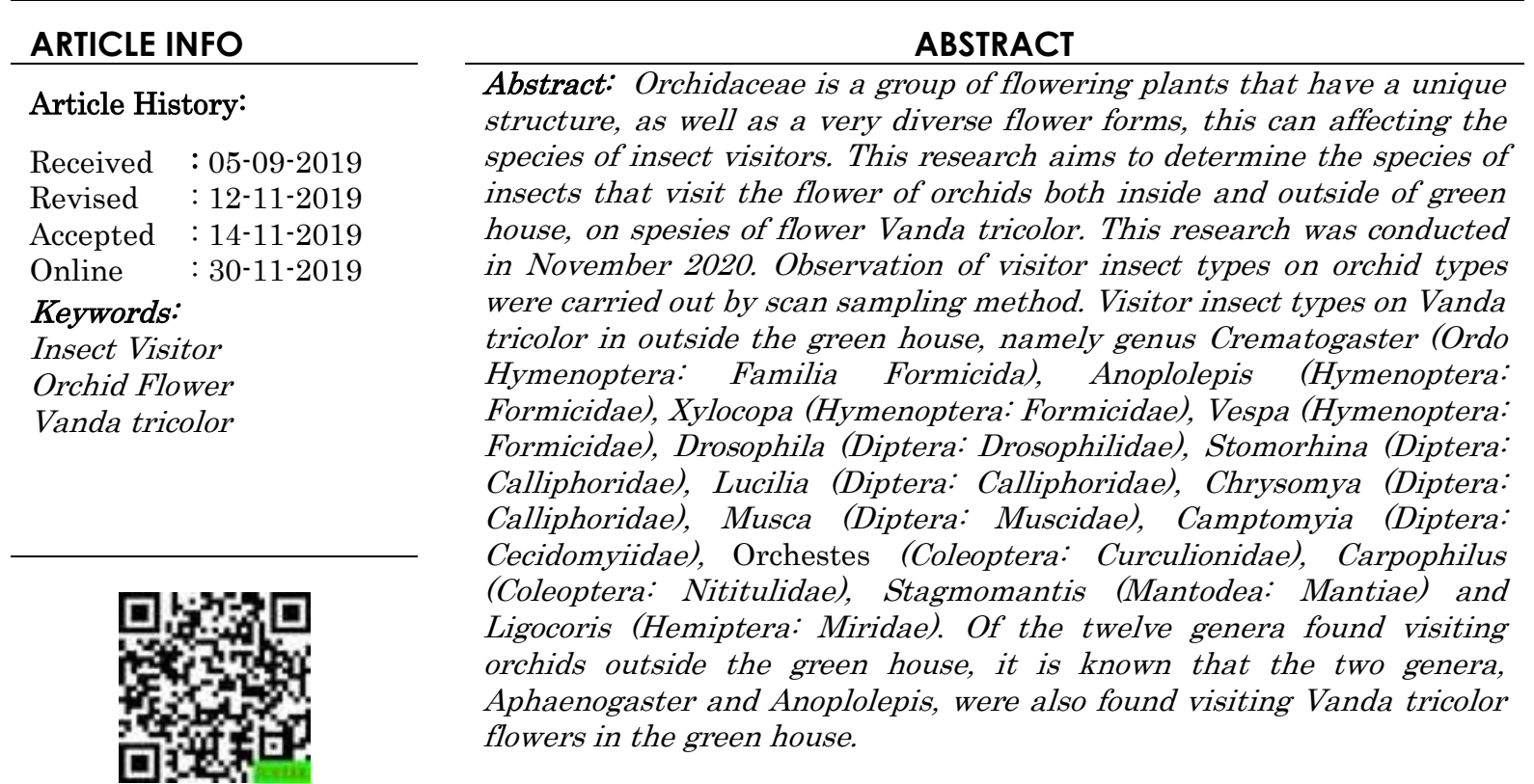

\begin{abstract}
Abstrak: Orchidaceae merupakan kelompok tumbuhan berbunga yang memiliki struktur unik, serta bentuk bunga yang sangat beragam, hal ini dapat mempengaruhi jenis serangga pengunjung. Penelitian ini bertujuan untuk mengetahui jenis serangga yang berkunjung pada bunga anggrek baik di dalam maupun diluar green house, khususnya spesies bunga anggrek Vanda tricolor. Penelitian ini dilaksanakan pada bulan November 2019. Pengamatan jenis serangga pengunjung pada jenis bunga anggrek dilakukan dengan metode scan sampling. Serangga pengunjung bunga Vanda tricolor di luar green house yaitu genus Crematogaster (anggota Ordo Hymenoptera: Familia Formicida), Anoplolepis (Hymenoptera: Formicidae), Xylocopa (Hymenoptera: Formicidae), Vespa (Hymenoptera: Formicidae), Drosophila (Diptera: Drosophilidae), Stomorhina (Diptera: Calliphoridae), Lucilia (Diptera: Calliphoridae), Chrysomya (Diptera: Calliphoridae), Musca (Diptera: Muscidae), Camptomyia (Diptera: Cecidomyiidae), Orchestes (Coleoptera: Curculionidae), Carpophilus (Coleoptera: Nititulidae), Stagmomantis (Mantodea: Mantiae) dan Ligocoris (Hemiptera: Miridae). Dari ke dua belas genus yang ditemukan mengunjungi bunga anggrek di luar green house, diketahui bahwa kedua genus yaitu Aphaenogaster dan Anoplolepis juga ditemukan mengunjungi bunga Vanda tricolor yang berada di dalam green house.
\end{abstract}




\section{A. LATAR BELAKANG}

Orchidaceae, merupakan salah satu familia terbesar dari kelompok tumbuhan berbunga (Angiospermae) dengan anggota mencapai 30.000 spesies, dan memberikan kontribusi hampir $10 \%$ dari semua spesies tumbuhan berbunga di dunia (Lucky dan Ravi, 2011). Secara umum familia Orchidaceae memiliki struktur bunga yang unik, khas dan menjadi ciri yang membedakannya dari familia lain pada kelompok tumbuhan bebunga. Struktur bunga yng dimiliki oleh familia Orchidaceae tidak memungkinkan melakukan mekanisme penyerbukan sendiri (Self-pollination) dan memerlukan agen penyerbuk (pollinator) berupa serangga untuk membantu proses penyerbukan (Lucky dan Ravi, 2011). Serangga membantu penyerbukan silang yang memberikan keuntungan bagi tumbuhan berupa pencampuran dan rekombinasi materi genetik yang dapat meningkatkan heterogenitas keturunannya (Sukmawati et al., 2020; Trianto et al., 2020). Selain itu, penyerbukan silang juga meningkatkan fitness, kualitas dan kuantitas biji dan buah, serta dapat mencegah kepunahan spesies tumbuhan (Trianto dan Marisa, 2020).

Arsitektur bunga yang meliputi ukuran, kedudukan organ reproduksi, bagian bunga yang menunjang serangga atau organisme lainnya untuk mengambil nektar, struktur bunga dan masa pembungaan, mempengaruhi interaksi antara tumbuhan dengan serangga pengunjung, khususnya agen penyerbuknya (Trianto et al., 2020). Sebagian besar agen penyerbuk menunjukkan variasi yang spesifik dalam hal ukuran tubuh, kemampuan sensorik, perilaku pencarian makan dan sumber energi yang dibutuhkan, sehingga ada hubungan tertentu yang secara umum dapat ditarik antara arsitektur perbungaan dengan tipe penyerbuk (Somanathan dan Borges, 2001).

Studi ilmiah mengenai hubungan antara spesies bunga anggrek dan agen penyerbuk spesifik (terjadi proses spesialisasi) sangat penting, karena berkaitan dengan sejarah kehidupan, distribusi, dan perilaku spesies secara individual maupun struktur serta fungsi sistem alam pada tingkat populasi, komunitas dan ekosistem. Dalam hal evolusi dan ekologi terjadinya spesialisasi yang merupakan hasil dari adaptasi, menyebabkan jenis anggrek terancam mengalami kepunahan (Trianto dan Purwanto, 2020). Penelitian ini bertujuan untuk menginformasikan jenis serangga pengunjung pada spesies bunga anggrek Vanda tricolor.

\section{B. METODE PENELITIAN}

Penelitian ini dilaksanakan pada bulan November 2019. Penelitian dibagi dalam tiga tahap, yaitu persiapan dan survei tempat, pengambilan data dan spesimen di lapang, serta identifikasi jenis serangga di Laboratorium Biologi Fakultas Keguruan dan Ilmu Pendidikan Universitas Tadulako.

Jenis anggrek yang digunakan adalah Vanda tricolor yang berada di dalam dan di luar green house sehingga dapat berinteraksi langsung dengan lingkungan luar. Pengamatan jenis serangga pengunjung pada jenis bunga anggrek dilakukan dengan metode scan sampling (Klein et al., 2002). Pengamatan dilakukan pada satu karangan bunga anggrek di lokasi pengamatan. Pengamatan dilakukan selama 3 hari dalam seminggu dan setiap jam dilakukan pengamatan selama 30 menit, mulai pukul 07.00 - 17.00 WITA. 
Serangga yang belum diketahui namanya ditangkap untuk keperluan identifikasi. Spesimen serangga yang berukuran relatif besar, diawetkan secara kering dengan memasukkan spesimen ke dalam oven pada suhu $37^{\circ} \mathrm{C}$ selama tujuh hari. Sedangkan spesimen yang kecil (Diptera, Thysanoptera, dan Ligocoris) diawetkan secara basah dalam alkohol 70\% (Trianto dan Purwanto, 2020).

\section{HASIL DAN PEMBAHASAN}

Anggrek Vanda tricolor masuk ke dalam Subtribe Aeridineae yang merupakan anggrek dengan habitus monopodial (Sulistyono, 2011). Menurut Dwiyani et al. (2012) Vanda tricolor memiliki bunga berukuran sekitar $7 \mathrm{~cm}$ dan beraroma harum; daun kelopak (sepals) (Gambar 1a) dan daun mahkota (petals) (Gambar 1b) memiliki bentuk seperti sendok, dengan warna putih di permukaan luarnya (Gambar 1). Pada permukaan bagian dalam dengan berbagai warna, dan paling sering dengan bintik-bintik merahkecoklatan dengan latar belakang berwarna putih, tetapi kadang-kadang dengan bintikbintik kuning pucat dan jarang sekali dengan bercak berwarna merah, seperti menyatu menutupi sebagian besar daun kelopak dan daun mahkota. Bibir (labellum atau lip) biasanya berwarna lembayung muda, putih atau kuning, keping sisi yang mendukung bibir berukuran $6 \times 6 \mathrm{~mm}$ dan memiliki keping tengah yang besar dengan tiga tonjolan (ridge) ditengah (Gambar 1e) (Jitsopakul et al., 2012). Pada bunga Vanda tricolor, polinia dihubungkan dengan gymnostemium (Gambar 1c) oleh stipes yang menumpu pada viscidium melekat di selaput rostellum (Gambar 1e), dan ketika polinia lepas dari clinandrium, maka stipes akan melengkung ke belakang sehingga dapat bertemu dengan stigma (Sulityono, 2011). Dengan adanya kunjungan agen penyerbuk maka akan mempercepat proses pelepasan polinia dari clinandrium dan dapat menyebabkan transfer polinia ke bunga dari tumbuhan lain.

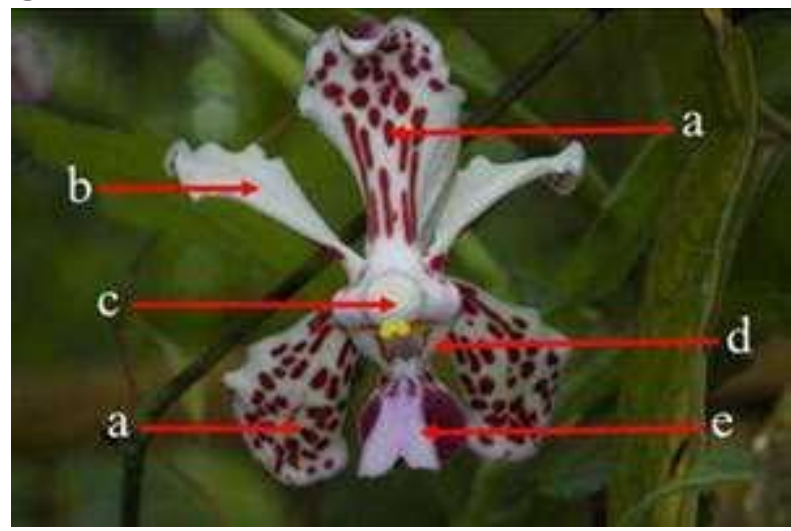

Gambar 1. Bunga Vanda tricolor; a. daun kelopak (sepal), b. daun mahkota (petal), c. gynostemium, d. keping samping (side lobe), dan e. keping tengah (mid lobe)

Berdasarkan hasil pengamatan jenis serangga yang mengunjungi bunga Vanda tricolor di dalam green house yaitu Aphaenogaster sp. dan Anoplolepis sp. Yang merupakan anggota dari Familia Formicidae. Kedua semut ini secara aktif melakukan kunjungan pada bunga Vanda tricolor dan melakukan kontak dengan gymnostemium (Gambar 2a dan 3b). 


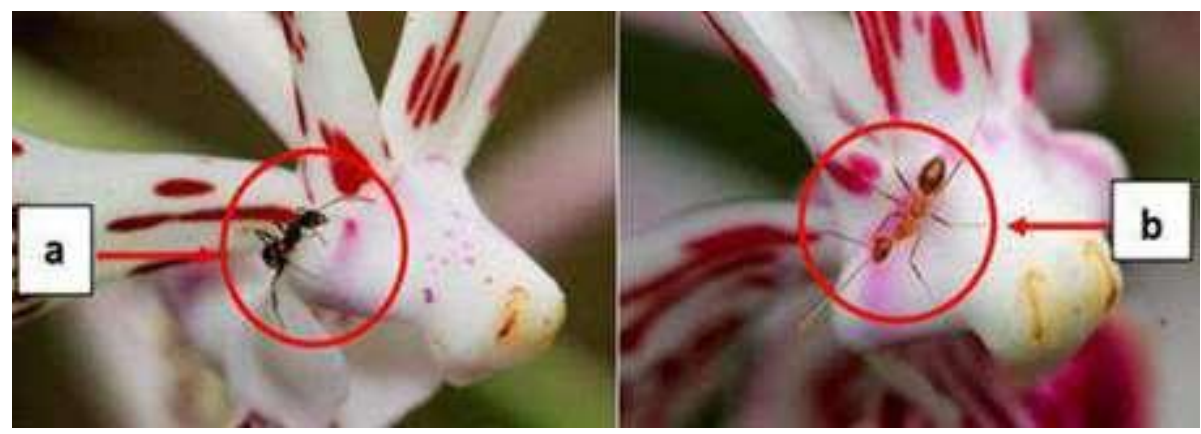

Gambar 2. Genus serangga pengunjung pada bunga Vanda tricolor di dalam green house, a. Aphaenogaster dan b. Anoplolepis

Serangga pengunjung bunga Vanda tricolor di luar green house yaitu genus Crematogaster, Anoplolepis, Xylocopa, Vespa (Hymenoptera: Formicidae), Drosophila (Diptera: Drosophilidae), Stomorhina, Lucilia, Chrysomya (Diptera: Calliphoridae), Musca (Diptera: Muscidae), Camptomyia (Diptera: Cecidomyiidae), Orchestes (Coleoptera: Curculionidae), Carpophilus (Coleoptera: Nititulidae), Stagmomantis (Mantodea: Mantiae) dan Ligocoris (Hemiptera: Miridae) (Gambar 3). Dari ke dua belas genus yang ditemukan mengunjungi bunga anggrek di luar green house, diketahui bahwa kedua genus yaitu Aphaenogaster (Gambar 2a) dan Anoplolepis (Gambar 2b) juga ditemukan mengunjungi bunga Vanda tricolor yang berada di dalam green house (Gambar 2).

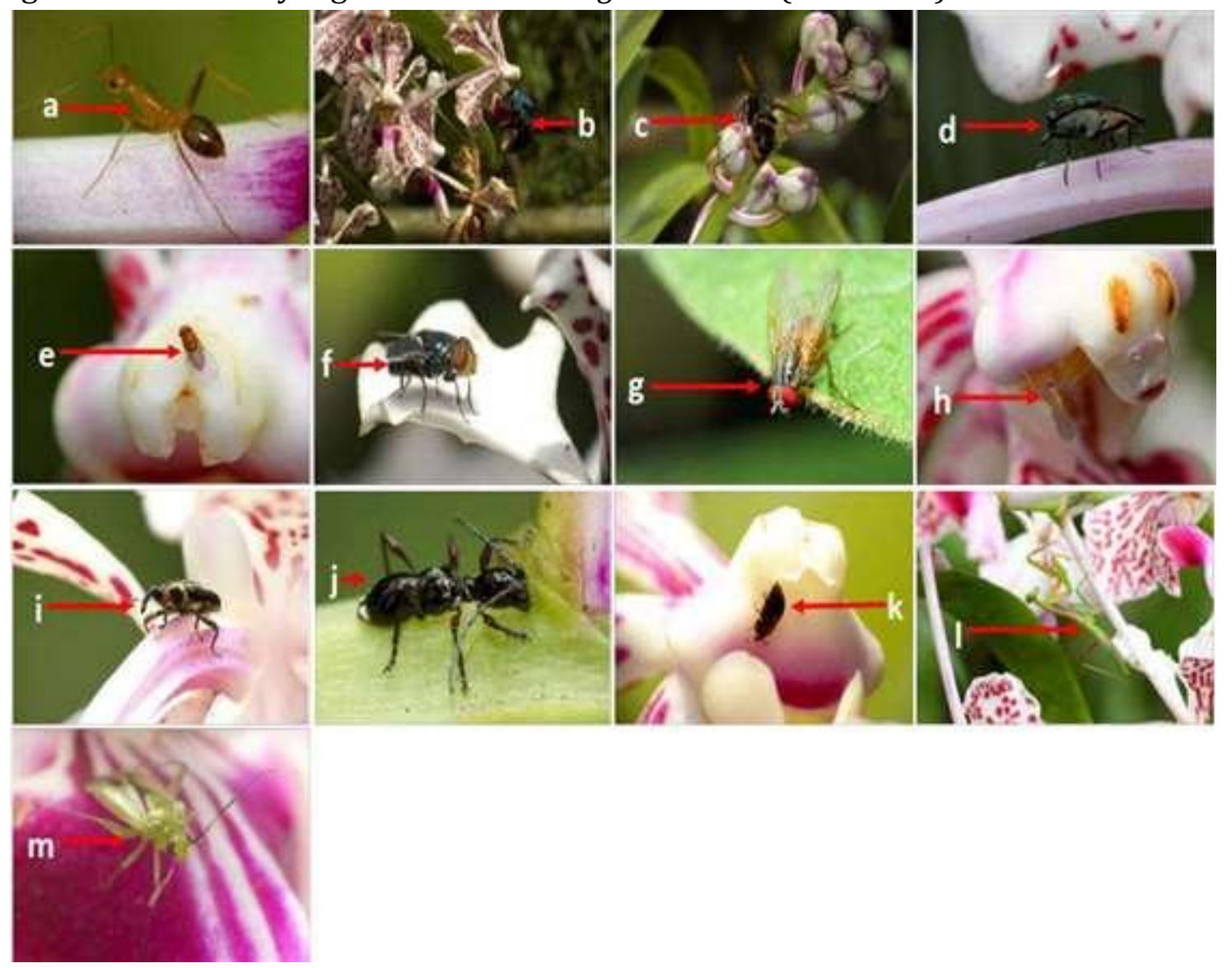

Gambar 3. Genus serangga pengunjung pada bunga Vanda tricolor di diluar green house, a. Anoplolepis; b. Xylocopa; c. Vespa; d. Stomorhina; e. Drosophila, f. Camptomyia; g. Musca; h. Camptomyia i. Orchestes, j. Clytellus, k. Carpophilus; 1. Stagmomantis; dan m. Ligocoris 
Xylocopa berpotensi sebagai agen penyerbuk karena serangga tersebut yaitu berukuran besar antara 12-26 mm, terbang sangat cepat dan kuat sehingga mampu beraktifitas pada kondisi angin kencang. Dengan ukuran tubuh yang besar dan kuat, Xylocopa dapat masuk menyeruak ke dalam bunga untuk mencapai dasar bunga yang banyak mengandung nektar (Trianto dan Marisa, 2020), dan memiliki kemampuan untuk mengekstrak polinaria dari bunga dengan perilakunya yang selalu aktif dan berdengung, sehingga polinaria menempel pada tubuh Xylocopa yang dipenuhi oleh rambut. Xylocopa diketahui sering mengunjungi bunga Vanda dan secara alami dapat membentuk persilangan (hybrid) melalui proses penyerbukan silang. Xylocopa (Carpenter bees) merupakan agen penyerbuk bagi bunga anggrek dari genus Vanda (Lucky dan Ravi, 2011). Xylocopa memiliki tubuh yang besar dan kuat, dan bunga yang menggunakan agen penyerbuk dari genus Xylocopa memiliki brakhtea, tekstur bunga yang kuat dan dasar bunga yang sangat keras.

Vespa atau kelompok tawon (Hymenoptera: Vespidae) merupakan serangga predator, disamping itu dapat di indikasikan juga sebagai agen penyerbuk karena dalam berburu mangsa secara tidak sengaja serangga ini juga melakukan transfer serbuk sari selain itu jenis dari Vespidae memiliki daya jelajah yang tinggi, dimana sepajang hari imagonya aktif terbang dan mampu terbang cukup jauh. Selain predator, kelompok Vespidae juga memakan nektar bunga, sehingga dapat menjadi serangga penyerbuk. Beberapa tawon mengunjungi bunga karena tertarik untuk memangsa pengunjung bunga lainnya. Selain itu, bau yang dikeluarkan oleh bunga dapat menarik kelompok tawon untuk berkunjung diindikasikan dengan perilaku terbang tawon yang "zig-zag" (Fajarwati et al., 2016; Nuraini et al., 2020). Menurut Arifin (2014) keberadaan tawon sangat penting bagi penyerbukan beberapa tumbuhan, karena merupakan vektor serbuk sari bagi tumbuhan dan dalam beberapa kasus, tawon merupakan agen penyerbuk yang lebih efisien dibandingkan dengan lebah (Hymenoptera: Apidae).

Kelompok lalat dapat menjadi agen penyerbuk bagi tumbuhan yang tumbuh pada ketinggian tempat tertentu, dimana jumlah mereka banyak dan sebaliknya kelompok serangga lainnya jumlahnya lebih sedikit karena kelembaban yang sangat tinggi, intensitas cahaya yang rendah serta temperatur yang sangat rendah (Trianto et al., 2020). Ada dua tipe penyerbukan yang dibantu oleh kelompok lalat, yaitu myophili dan Sapromyophili. Myophili merupakan tipe penyerbukan yang di lakukan oleh kelompok lalat pemakan polinaria atau serbuk sari, dan melakukan kunjungan secara rutin terhadap bunga. Pada lalat buah (Tephritidae) jantan tertarik untuk mengunjungi bunga karena mengeluarkan atraktan berupa aroma khususnya pada beberapa anggrek liar yang tidak menghasilkan nektar. Atraktan ini berfungsi sebagai prekursor feromon seks bagi lalat buah. Pada tipe penyerbukan sapromyophili, lalat mengunjungi bunga karena bunga tersebut mengeluarkan bau atau aroma seperti bangkai atau kotoran. Genus Stomorhina, Chrysomya, Musca dan Drosophila merupakan anggota diptera yang selama pengamatan diketahui mengunjungi bunga Vanda tricolor. Banyak larva dari anggota Familia Muscidae, Calliporidae dan Sarcophadidae hidup di dalam bangkai hewan, kotoran dan tumbuhan yang membusuk. Lalat dari famili ini, khususnya Calliphoridae sering berkunjung ke berbagai bunga dengan nektar yang mudah diakses di seluruh 
bagian bunga tersebut. Mereka sangat berperan dalam proses penyerbukan, karena merupakan serangga penerbang yang kuat dan dapat membawa polinaria yang relatif banyak (Corlett, 2004). Kelompok Diptera pada fase dewasa sebagian besar makannya berupa cairan, sehingga alat mulut termodifikasi menjadi penusuk dan penghisap atau penjilat. Banyak juga jenis diptera yang dapat memakan partikel kecil solid seperti polinaria yang kemudian tersuspensi di dalam air liur. Lalat memungkinkan menjadi agen penyerbuk selain lebah, dan merupakan serangga pengunjung bunga. Beberapa bunga anggrek memiiki aroma yang sangat kuat, sehingga dapat menarik lalat untuk berkunjung ke bunga tersebut (Pedersen, 1995; Pratama dan Trianto, 2020).

Kelompok kumbang atau beetle (Ordo Coleoptera) mengunjungi bunga untuk mengambil nektar, serbuk sari atau makanan lainnya yang terdapat pada bunga; untuk melakukan perkawinan atau meletakkan telur pada substrat yang berupa bagian bunga. Karakteristik bunga yang tampak, jika bunga tersebut dapat dikunjungi dan diserbuki dengan bantuan kumbang yaitu bunga memiliki aroma yang sangat kuat, aroma tersebut mulai dari manis, berasa seperti buah, sampai berbau seperti benda lapuk. Bunga dengan wewangian kimiawi (eugenol, benzyl acetae, methyl benzoat dan linalool) sebagai umpan untuk menarik kumbang yang berpotensi sebagai agen penyerbuk, terutama Famili Scarabidae, Mordellidae, Curculionidae dan Cerambycidae (Erniwati dan Kahono, 2012). Orchestes, Clytellus dan Carpophilus merupakan kelompok kumbang yang masuk ke dalam Ordo Coleoptera. Sebagian besar kelompok kumbang memakan polinaria dan nektar. beberapa spesies memiliki adaptasi perilaku seperti lebah. Dalam beberapa kasus. Beberapa famili anggota Coleoptera dapat mengunjungi satu bunga yang sama; atau satu famili anggota Coleoptera mengunjungi bunga dari lebih satu spesies tumbuhan. Penyerbukan yang dibantu oleh kumbang di laporkan pernah terjadi pada Vanda cristata. Pada penelitian ini, genus Orchestes dan Clytellus hanya ditemukan pada bunga Vanda tricolor saja. Sedangkan genus Carpophilus selain ditemukan pada bunga Vanda tricolor juga mengunjungi bunga Coelogyne speciosa.

Seperti halnya Familia Diptera dan Coleoptera, Hemiptera juga dapat menjadi agen penyerbuk karena tingginya aktivitasnya pada bunga. Dominansi kunjungan Hemiptera (Famili Miridae) pada bunga, dibandingkan dengan pengunjung bunga lainnya (Trianto dan Marisa, 2020). Sejauh ini, penelitian dari Ishida et al. (2009) merupakan laporan pertama yang menyatakan bahwa Hemiptera merupakan agen penyerbuk utama pada tumbuhan dari genus Macaranga (Euphorbiaceae). Hanya beberapa studi yang menyatakan bahwa kelompok Hemiptera sebagai agen penyerbuk, meskipun demikian beberapa hasil penelitian menyatakan bahwa kelompok Hemiptera ditemukan mengunjungi bunga untuk menyerap getah tumbuhan atau memangsa serangga lain yang mengunjungi bunga seperti kutu daun (Ordo Thysanoptera) (Suprianto et al., 2020).

Perpindahan serangga dari satu bunga ke bunga yang lain baik dalam satu tumbuhan (geitonogami) maupun tumbuhan yang berbeda (xenogami) dapat berperan sebagai agen penyerbuk, namun demikian tidak semua serangga yang berkunjung berpotensi sebagai agen penyerbuk. Pada penelitian ini, serangga pengunjung yang mengunjungi bunga anggrek baik di dalam maupun di luar green house dan tidak 
berperan sebagai serangga penyerbuk adalah Camptomyia (Diptera: Cecidomyiidae) dan Stagmomantis (Mantodea: Mantide). Pengunjung bunga (flower visitor) dapat diduga sebagai agen pembantu penyerbukan jika organisme tersebut dapat memastikan terjadinya transfer serbuk sari pada kepala putik. Menurut Grifin dan Sedgley (1989) penyerbuk disebut sebagai penyerbuk efektif apabila dapat mengadakan kunjungan yang tetap pada bunga saat serbuk sari masak dan putik reseptif, melakukan aktivitas pada kisaran kondisi cuaca (iklim) yang sama dengan musim bunga, mengunjungi banyak bunga pada banyak tumbuhn dalam satu populasi, membawa muatan tepung sari yang mencukupi, membuat kontak yang kontinu dengan kepala putik, dengan cara yang dapat mengakibatkan terjadinya penyerbukan, dan terdapat dalam jumlah yang mencukupi. Stagmomantis (Mantodea) merupakan serangga predator yang ditemukan mengunjungi bunga Vanda tricolor dan umumnya mencari pakan berupa serangga kecil. Stagmomantis bukan termasuk serangga yang dapat membantu penyerbukan. Meskipun dapat membawa serbuk polinaria, namun karena ukuran tubuhnya yang besar serangga ini tidak mampu melakukan kontak dengan organ reproduksi betina khususnya kepala putik yang posisinya berada di dalam collumn, sehingga tidak terjadi transfer serbuk.

\section{SIMPULAN DAN SARAN}

Serangga pengunjung pada spesies bunga anggrek Vanda tricolor terdiri atas 12 genus dengan komposisi yaitu di luar green house (Crematogaste, Anoplolepis, Xylocopa, Vespa, Drosophila, Stomorhina, Lucilia, Chrysomya, Musca, Camptomyia, Orchestes, Carpophilus, Stagmomantis, dan Ligocoris) dan di dalam green house (Aphaenogaster dan Anoplolepis).

Sebaiknya dilakukan penelitian serupa pada berbagai spesies bunga anggrek agar diperoleh data serangga penyerbuk terbaik bagi bunga anggrek yang berada di dalam dan di luar green house.

\section{REFERENSI}

Arifin, I. (2014). Kenakearagaman Semut (Hymenoptera: Formicidae) Pada Berbagai Subzona Hutan Pegunungan di Sepanjang Jalur Pendakian Cibodas TNGGP. Bioma, 10(2), 1-10.

Corlett, R, T. (2004). Flower Visitor and Pollination in The Oriental (Indomalayan) Region. Biological Review, 9, 497-532.

Dirham, dan Trianto, M. (2020). Analisis Isi Lambung Ikan Mujair (Oreochromis mossambicus) di Perairan Danau Talaga Kabupaten Donggala. Jurnal BIO-EDU, 5(3), 118-128.

Dwiyani, R, Purwantoro, A, Indrianto, A, dan Semiarti, E. (2012). Konservasi Anggrek Alam Indonesia Vanda tricolor varietas Suavis Melalui Kultur Embrio Secara In Vitro. Jurnal Bumi Lestari, 12(1), 93-98.

Erniwati, E, dan Kahono, S. (2012). Keanekaragaman dan Potensi Musuh Alami dari Kumbang Elaeidobius kamerunicus di Perkenbunan Kelapa Sawit di Kabupaten Penajam Paser Utara. Zoo Indonesia. 21(2), 9-15.

Fajarwati, M, R, Atmowidi, T, dan Dorly, D. (2016). Keanekaragaman Serangga Pada Bunga Tomat di Lahan Pertanian Organik. Jurnal Entomologi Indonesia, 6(2), 77.

Griffin, A, R, dan Sedgley, M. (1989). Sexual Reproduction of Tree Crops. London: Academic Press Ltd., p. 379.

Ishida, C, K, Masumi, dan Shoko, S. (2009). A New Pollination System: Brood-Site Pollination by Flower Bugs in Macaranga (Euphorbiaceae). Annals of Botany, 103(1), 39-44. 
Jitsopakul, N, Thammasiri, K, Yuwaka, T, dan Ishikawa, K. (2012). Effect of cryopreservation on seed germination and protocorm development of Vanda tricolor. ScienceAsia, 38(3), 244-249.

Klein, A, M, Steffan-Dewenter, D, Buchori, dan Tscharntke, T. (2002). Effects of Land Use Intensif in Tropical Agroforestry Systems on Coffe Flowervisiting and Trap-nesting Bees and Waps. Conserv Biol, 16, 1003-1014.

Lucky, K, A, dan Ravi, K. (2011). Orchid Pollination: An Observation on Pollination-Polliantor Interaction in Cymbidium pedulum, (Sw.) Roxb. Current Botany, 2(7), 5-8.

Nuraini, Trianto, M, Sukmawati, dan Marisa, F. (2020). Keanekaragaman Sumber Pakan dan Perilaku Mencari Pakan Lebah Tetragonula laeviceps (Hymenoptera: Meliponini) di Kecamatan Parigi Selatan. Jurnal BIO-EDU, 5(3), 173-184.

Pedersen, H, A. (1995). Anthecological Conservation on Dendrochilum longibracteatum- A Species Pollinated Bay Facultatively Anthophilous Insect. Lindleyana, 10, 19-28.

Pratama, A, dan Trianto, M. (2020). Keanekaragaman Lichen di Hutan Mangrove Desa Tomoli Kabupaten Parigi Moutong. Jurnal BIO-EDU, 5(3), 140-150.

Raju, A, J, S, dan Ezradanam, V. (2002). Pollination Ecology and Fruiting Behavior in a Monoecious spesies, Jatropha curcas L. (Euphorbiaceae). In Flowering and Fruit Set Under Malaysian Climate of Jatropha curcas L. American Journal of Agricultural and Biological Sciences, 6(1), 142-147.

Somanathan, H, dan Borges, R, M. (2001). Nocturnal Pollination by the Carpenter Bee Xylocopa tenuiscapa (Apidae) and the Effect of Flora Display on Fruit Set of Heterophragma quadriloculare (Bignoniaceae) in India. Flower Visitor and Pollination in The Oriental (Indomalayan) Region. Biological Review, 9(1), 497-532.

Sukmawati, Trianto, M, dan Nuraini. Hubungan Kekerabatan Intraspesies Tanaman Puring (Codiaeum variegatum L.) di Kecamatan Parigi Selatan Berdasarkan Analisis Fenetik. Jurnal BIO-EDU, 5(3), 161-172.

Sulistyono. (2011). Buku Panduan Identifikasi Anggrek Merapi. Edisi 1. Yogyakarta: Yayasan Kanopi Indonesia.

Suprianto, Trianto, M, Alam, N, dan Kirana, N. G. A. G. C. (2020). Karakter morfologi dan analisis daerah conserved gen elongation factor 1a (EF1a) pada Lepidotrigona terminata. Jurnal Metamorfosa, 7(2), 30-39.

Trianto, M, dan Marisa, F. (2020). Diversity of Bees and Wasp (Hymenoptera) in Cowpea (Vigna sinensis L.) in Agricultural Area at Martapura District, Banjar Regency, South Kalimantan. Journal of Science and Technology, 9(2), 29-33.

Trianto, M, dan Marisa, F. (2020). Studi Kelimpahan dan Pola Sebaran Collembola pada Tiga Tipe Penggunaan Lahan di Kabupaten Banjar, Kalimantan Selatan. Jurnal BIO-EDU, 5(3), 107-117.

Trianto, M, dan Purwanto, H. (2020). Molecular phylogeny of stingless bees in the Special Region of Yogyakarta revealed using partial 16S rRNA mitochondrial gene. Buletin Peternakan, 44(4), 186-193.

Trianto, M, dan Purwanto, H. (2020). Morphological characteristics and morphometrics of Stingless Bees (Hymenoptera: Meliponini) in Yogyakarta, Indonesia. Biodiversitas, 21(6), 2619-2628.

Trianto, M, Kaini, Saliyem, Warsih, E, dan Winarsih. (2020). Keanekaragaman Serangga Polinator pada Tanaman Nanas (Ananas comosus (L.) Merr.) di Desa Bincau. Jurnal Penelitian Science dan Pendidikan, 9(2), 154-162.

Trianto, M, Marisa, F, dan Siswandari, N.P. (2020). Kelimpahan Nisbi, Frekuensi, dan Dominansi Jenis Lalat di Beberapa Pasar Tradisional di Kecamatan Martapura. Jurnal Metamorfosa, 7(2), 2129.

Tuwo, M, dan Indrianto, A. (2016). Improvement of Orchid Vanda Hybrid (Vanda limbata Blume X Vanda tricolor Lindl. Var. suavis) by Colchicines Treatment In Vitro. Modern Applied Science, 10(11), 83-89. 